\title{
Nepenthes samar (Nepenthaceae), a new species from Samar, Philippines
}

\author{
M. Cheek ${ }^{1}$, M. Jebb ${ }^{2}$
}

\section{Key words}

conservation

Nepenthes

Philippines

Samar

Visayas
Abstract Nepenthes samar is described from the island of Samar in the Visayas of the Philippines. Similar to N. merrilliana of Mindanao, it is distinguished on foliar and floral characteristics and assessed as Critically Endangered using the IUCN 2001 standard.

Published on 10 September 2013

\section{INTRODUCTION}

This paper forms part of studies towards a World Monograph of Nepenthes, building on a Skeletal Revision of Nepenthes (Jebb \& Cheek 1997) and the Flora Malesiana account (Cheek \& Jebb 2001). In the course of studying previously unseen specimens from the Philippines, two collections (Gaerlan \& Chavez 26372, 26416, both BRIT), of an unknown species, came to light from Samar in the eastern Visayas.

The ligulate, sessile leaf-blades with 5-6 pairs of nearly evenlyspread longitudinal nerves placed the species in the Insignes group of Danser (1928) which are for the most part restricted to the Philippines (Cheek \& Jebb 2001). Further characters that distinguish this group are given in Cheek \& Jebb (2013).

The Samar material has only upper pitchers and not lower, which is also an attribute of two species of the Insignes group, $N$. ventricosa Blanco (1837: 807) which is found in Luzon and Panay, and N. burkei Mast. (1889: 492) which is found in Mindoro. In these two species, both of which are extensively cultivated, lower pitchers are produced either not at all or very rarely and inconspicuously before the plants develop upper pitchers (Cheek \& Jebb 2001). Both these species have broadly cylindrical upper pitchers (as is usual in the group), but which are more or less constricted at the middle, while the Samar material has cylindrical to narrowly infundibular upper pitchers. Nepenthes merrilliana Macfarl. (1911: 207) of Surigao Province in NE Mindanao is the species of the Insignes group closest geographically, and in overall dimensions, to the Samar species. However, of the 12 specimens known of $N$. merrilliana only one features upper pitchers, the remainder bearing only lower pitchers, including those with inflorescences, suggesting that upper pitchers are produced infrequently in this species, the opposite of the case in the Samar material. The two species differ further, in leaf-blade, pitcher, and inflorescence characters as shown in Table 1. Accordingly, $N$. samar is here described as new to science.

\footnotetext{
Royal Botanic Gardens, Kew, Richmond, Surrey, TW9 3AE, UK; corresponding author e-mail: m.cheek@kew.org

2 National Botanic Garden, Glasnevin, Dublin 9, Republic of Ireland.
}

Nepenthes samar Jebb \& Cheek, sp. nov. - Fig. 1

A N. merrilliana Macfarl. ascidia superioria multo efferentibus sed ascidiis inferioribus nullis; laminis ad apicem angustatis (non obtusis nec rotundatis nec retusis), $2.8-3.2 \mathrm{~cm}$ (non $3.6-5.5 \mathrm{~cm}$ ) latis, ad basim $0.6-0.8 \mathrm{~cm}$ (non $1.5-3 \mathrm{~cm}$ ); margine interiore peristomatis manifeste visibili (non reflexo nec inconspicuo); pagina exteriore tepalorum ad centrum pilis carentibus nec modice hirta differt. - Typus: Gaerlan \& Chavez in PPI 26416 (holo BRIT; iso PNH n.v.), Philippines, Visayas, Luzon, Samar (exact locality withheld for conservation reasons), infructescence 21 Aug. 1996.

Etymology. Named as a noun in apposition for the island of Samar.

Terrestrial shrub-climber, probably to several metres high, stems quadrangular, not winged, 5-7(-9) mm diam, internodes of climbing stems $(2.5-) 3-8 \mathrm{~cm}$ long, axillary buds not seen, indumentum of red, flattened glands $0.05 \mathrm{~mm}$ diam, very young growth with thinly scattered simple appressed hairs $0.5 \mathrm{~mm}$ long, soon glabrescent, surface matt, green. Leaves of rosette and short stems not known, leaves of climbing stems spirally inserted, papery, matt, linear-oblong $22-32$ by $2.8-3.2 \mathrm{~cm}$, apex attenuate, not peltate, base steadily attenuate in the proximal $5 \mathrm{~cm}$, subpetiolate, the base $0.6-0.8 \mathrm{~cm}$ broad, clasping the stem for $1 / 3$ its circumference and decurrent as a wing $0.8-1$ by $0.1-0.3 \mathrm{~cm}$, continuing down the stem as a ridge, longitudinal nerves 5-6 pairs, evenly distributed, conspicuous on upper surface; pennate nerves numerous, arising at $45^{\circ}$ from the midrib, branching, conspicuous, upper surface glabrous, lower surface with indumentum as the stem. Lower and intermediate pitchers not seen. Upper pitchers (tendrils coiled), cylindric or narrowly infundibuliform, $12-25$ by $4-6(-8) \mathrm{cm}$; outer surface with minute red globose glands $0.05 \mathrm{~mm}, \mathrm{c} .10$ per $\mathrm{mm}^{2}$ and sparse appressed simple hairs $0.2-0.9 \mathrm{~mm}$ long; minute, short-armed dendritic erect hairs $0.1 \mathrm{~mm}$ long below the peristome; green, spotted red, with peristome red. Fringed wings absent, reduced to ridges running the length of the pitcher. Mouth ovate, oblique, concave, $4-8$ by $6 \mathrm{~cm}$, peristome rounded, $6-14 \mathrm{~mm}$ wide, $0.8-1.4$ ridges per $\mathrm{mm}$, ridges 0.1-0.25 mm high, inner edge not revolute, but directed to base of pitcher, teeth minute, alternating with holes, plainly visible, teeth broader than long, $0.12-0.4$ by $0.25-0.5 \mathrm{~mm}$; outer edge shallowly lobed, or not; column not strongly developed; lid broadly elliptic, (3-)6-7 by $4.7-6.5 \mathrm{~cm}$, apex rounded to truncate, base rounded or shortly and abruptly cordate; lower surface lacking basal appendage, with a shallow midline ridge 


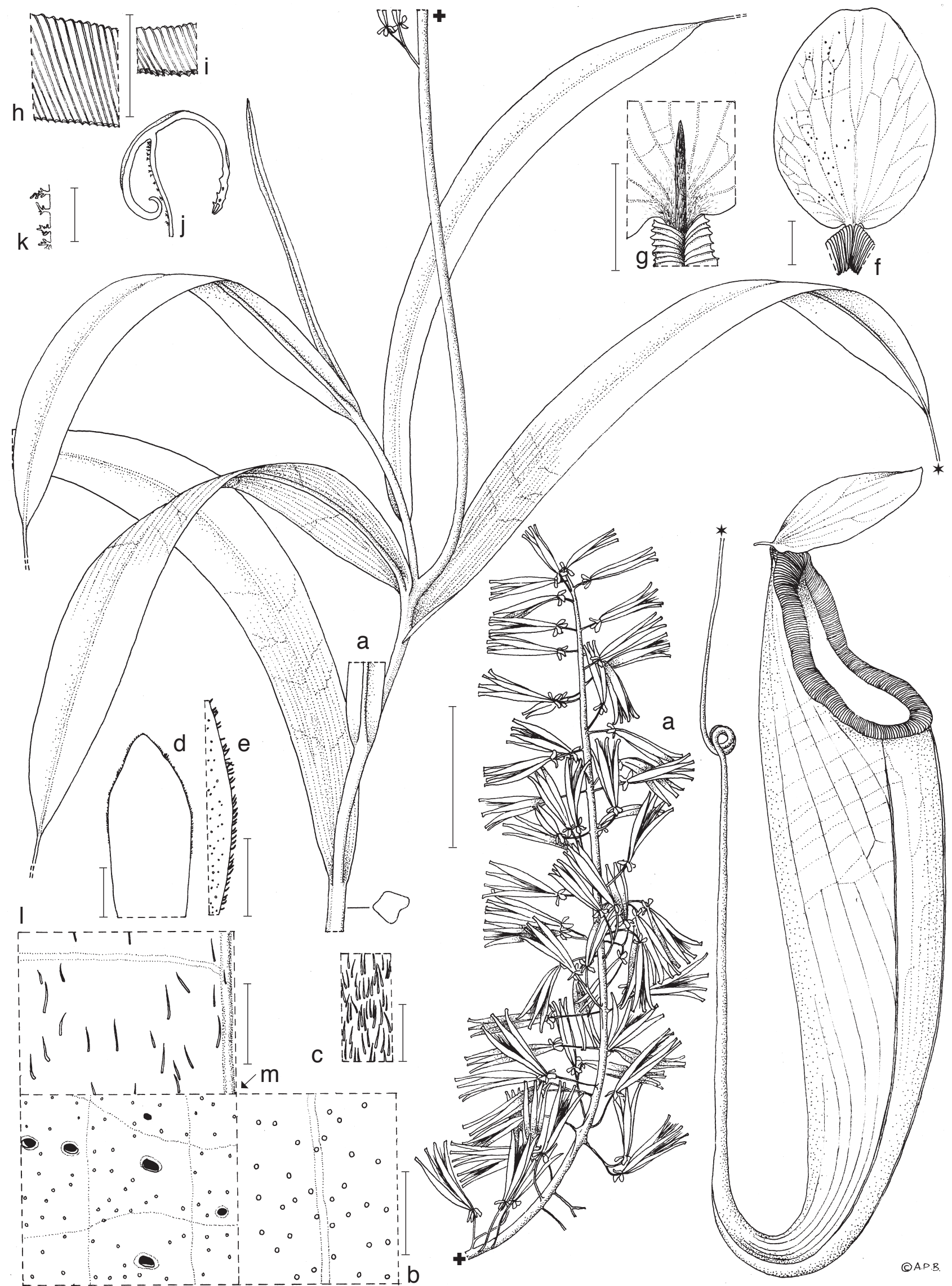

Fig. 1 Nepenthes samar Jebb \& Cheek. a. Habit, with climbing stem, upper pitcher (after rehydration), infructescence and transverse section of stem; b. lower surface of leaf with sessile glands and a pennate nerve; c. pedicel indumentum; d. tepal, lower surface; e. detail of d showing margin; f. lid, lower surface, upper pitcher (nectar glands shown on left side only); g. spur; h. peristome near lid, viewed from above; i. peristome inner edge; j. peristome, transverse section (inner surface on right); k. dendritic hairs on outer pitcher below peristome; I. indumentum of outer pitcher surface with appressed simple hairs; m. detail of transversely elliptic nectar glands and sessile glands on lower surface of lid (Gaerlan \& Chavez in PPI 26416). - Scale bars: $a=5 \mathrm{~mm} ; \mathrm{b}, \mathrm{d}=1 \mathrm{~mm}$; $\mathrm{c}, \mathrm{e}, \mathrm{j}$, $\mathrm{k}=0.5 \mathrm{~mm} ; \mathrm{f}-\mathrm{i}=1 \mathrm{~cm} ; \mathrm{l}, \mathrm{m}=2 \mathrm{~mm}$. 
Table 1 The major characters separating N. samar and N. merrilliana.

\begin{tabular}{lll}
\hline & N. samar & N. merrilliana \\
\hline Climbing stems & Not winged & Winged \\
Leaf apex & Attenuate & Obtuse, rounded or retuse, rarely acute \\
Leaf base & Steadily attenuate, subpetiolate in the basal $5 \mathrm{~cm}$, & Slightly attenuate, but almost as wide as rest of blade, \\
& $0.6-0.8 \mathrm{~cm}$ broad at junction with stem & $1.5-3 \mathrm{~cm}$ broad at junction with stem \\
Leaf texture and surface & Papery, matt & Leathery, glossy \\
Lower / upper pitchers & Known only from upper pitchers & Known mainly from lower pitchers, upper pitchers infrequently produced \\
Peristome of upper pitchers & Inner part perpendicular, margin visible (Fig. 1I) & Inner part revolute, margin not visible without dissection \\
Outer tepal surface & Lacking hairs in central area & Moderately hairy
\end{tabular}

3-4 mm wide, c. $1 \mathrm{~mm}$ high; nectar glands sunken, sparse, transversely elliptic or orbicular, $0.25-0.4$ by $0.25-0.7(-0.9)$ $\mathrm{mm}$, borders thin, slightly raised, or absent, $40-50$ glands on each side of the midline, mainly absent from the central c. $8 \mathrm{~mm}$ band; minute red glands flush with surface, 0.05-0.07 mm diam, evenly scattered, dense, 5-10 $\mathrm{mm}$ per $\mathrm{mm}^{2}$; upper surface of lid with indumentum as outer pitcher. Spur cylindric, c. $10 \mathrm{~mm}$, apex acute, hirsute. Male and female inflorescence unknown. Infructescence (with persistent sepals) with peduncle $17 \mathrm{~cm}$ long, $5 \mathrm{~mm}$ diam indumentum at base covering 30-40\% of surface; simple hairs, $0.15-0.25 \mathrm{~mm}$ long, glossy, coppercoloured, mixed with minute red glands $0.05 \mathrm{~mm}$ diam; rhachis $29 \mathrm{~cm}$ long, bearing c. 100 partial-peduncles, 2-flowered (mainly at base of inflorescence) to 1-flowered (mainly at apex of inflorescence) partial-peduncles in ratio of $1: 2$; partial-peduncles (when 2-flowered) 7-9 mm long; bracts absent; pedicel 7-10 $\mathrm{mm}$ long, indumentum 80-90\% cover. Tepals 4, oblong, 2-3.5 by 1-1.7 mm, apex obtuse, lower surface glabrous apart from papillae, margin with short multicellular hairs, upper surface with nectar glands, glabrous. Fruit 25-28 mm long, glossy brown, dehiscing in 4 valves c. $3 \mathrm{~mm}$ wide, indumentum as pedicels but very sparse (2\%). Seeds 12 by $0.35 \mathrm{~mm}$, minutely papillate, embryonic area central, 1.75 by $0.35 \mathrm{~mm}$, with two or more tuberculate lines, pale brown.

Distribution \& Ecology — Philippines, Visayas, Samar, lowland Dipterocarp forest over ultramafics; low elevation.

Additional material. PHILIPPINES, Visayas, Samar (exact locality withheld for conservation reasons), Gaerlan \& Chavez in PPI 26372 (BRIT, PNH n.v.), 20 Aug. 1996,

Conservation - Nepenthes samar is known from only two collections, representing as many individuals at one location, in a nation which has seen extensive habitat clearance, especially of lowland forest. The specimen notes indicate that the area had been logged over. Inspection of Google Earth imagery (viewed March 2013) of the location shows that while woody vegetation persists, the canopy is open, suggesting marked degradation of the forest habitat, likely to be aggravated by being near a municipality (Gaerlan \& Chavez in PPI 26372). Although it was alive in the wild in 1996, this species may already be extinct as is thought to be the case with $N$. robcantleyi Cheek (2011: 678). Nepenthes samar is here assessed as Critically Endangered under IUCN (2001), Criterion D. It is to be hoped that this spectacular species will be rediscovered and brought into cultivation from seed and multiplied by a reputable nursery to reduce the risk of total extinction from unscrupulous commercial collectors of wild plants who have been known to decimate fragile populations of rare Nepenthes by digging them up.

Acknowledgements Janis Shillito typed the manuscript; Christine Barker translated the diagnosis, Andrew Brown drew the figure which Lee Davies digitised. Aaron Davies councilled on seeking, and Tiana Rehman facilitated, the BRIT loan. James Beattie and Rebecca Hilgenhof grew the flowering plants of $N$. merrilliana at the Tropical Nursery, Royal Botanic Gardens, Kew used for comparison with $N$. samar in conjunction with wild-gathered herbarium specimens.

\section{REFERENCES}

Blanco M. 1837. Flora de Filipinas. Manila, En la Inprenta de Sto. Thomas por D. Candido Lopez.

Cheek M. 2011. Nepenthes robcantleyi sp. nov. (Nepenthaceae) from Mindanao, Philippines. Nordic Journal of Botany 29: 677-681.

Cheek M, Jebb M. 2001. Nepenthaceae. In: Nooteboom HP (ed), Flora Malesiana 15. Nationaal Herbarium Nederland, Leiden.

Cheek M, Jebb M. 2013. Nepenthes alzapan (Nepenthaceae), a new species from Luzon, Philippines. Phytotaxa 100, 1: 57-60.

Danser BH. 1928. The Nepenthaceae of the Netherlands Indies. Bulletin du Jardin Botanique de Buitenzorg III, 9: 249-438.

IUCN 2001. IUCN Red List categories and criteria: version 3.1. Prepared by the IUCN Species Survival Commission. IUCN, Gland, Switzerland and Cambridge, UK.

Jebb M, Cheek M. 1997. A skeletal revision of Nepenthes. Blumea 42: 1-106. Macfarlane JM. 1911. New species of Nepenthes. Transactions and Proceedings of the Botanical Society of Pennsylvania 3: 207-210.

Masters MT. 1889. Nepenthes burkei. The Gardeners' Chronicle. Ser. 3, vol. 6: 492-493. 